\title{
Motivasi Masyarakat dalam Pemanfaatan Internet untuk Pengelolaan Sampah di Kecamatan Banyumanik, Kota Semarang
}

\author{
Vionna1, Maryono Maryono ${ }^{1,2}$ \\ 1 Departemen Perencanaan Wilayah dan Kota, Universitas Diponegoro, Indonesia. \\ ${ }^{2}$ Center for Infrastructure Resilience and Development. e-mail: vionna18@pwk.undip.ac.id
}

\begin{abstract}
ABSTRAK
Motivasi dalam pemanfaatan internet untuk pengelolaan sampah menjadi salah satu faktor pendorong untuk mewujudkan Smart Waste Management (SWM). Adanya motivasi tersebut bertujuan untuk dapat merubah perilaku masyarakat dalam pengelolaan sampah dari kumpul-angkut-buang menjadi pengurangan dan penanganan dari hulu dan hilir yang dapat dilakukan melalui bantuan teknologi dalam sistem pengelolaannya yang dikenal Internet of Things (IoT). Kota Semarang terpilih sebagai salah satu kota yang tergabung dalam Gerakan Menuju 100 Smart city pada Smart city Summit tahun 2017. Namun, belum ada pemanfaatan internet sebagai salah satu alat untuk mengurangi permasalahan persampahan yang keberhasilannya ditentukan oleh masyarakat. Kecamatan Banyumanik merupakan kecamatan dengan jumlah bank sampah aktif terbanyak di Kota Semarang. Namun, berdasarkan data Masterplan Persampahan Kota Semarang terakhir pada tahun 2013, tingkat pelayanan persampahan di Kecamatan Banyumanik masih 27\% yaitu berada di posisi ke-10 dari 16 Kecamatan di Kota Semarang. Hal tersebut tidak sebanding dengan timbulan sampah yang mencapai 365,88 $\mathrm{m}^{3} / \mathrm{hari} \mathrm{dan}$ menjadikan Kecamatan Banyumanik penyumbang timbulan sampah terbanyak keempat se-Kota Semarang. Penelitian ini mengumpulkan data dari 200 orang responden yang telah terlayani sarana persampahan dan telah menggunakan internet di Kecamatan Banyumanik menggunakan skala Likert 1-7. Menggunakan Structural Equation Modeling (SEM), penelitian ini menguji faktor-faktor yang memengaruhi motivasi masyarakat dalam pemanfaatan internet untuk pengelolaan sampah. Berdasarkan kondisi sosio-demografis, ekonomi dan sistem persampahan yang ada di Kecamatan Banyumanik, peneliti menemukan bahwa faktor pengetahuan terhadap internet dan daur ulang adalah faktor terpenting yang memengaruhi motivasi masyarakat dengan koefisien korelasi 1,02. Faktor lain yang berpengaruh adalah kondisi sarana persampahan itu sendiri dengan koefisien korelasi 0,74. Dengan demikian, penelitian ini merekomendasikan pemerintah mempromosikan IoT untuk pengelolaan sampah seperti adanya aplikasi edukasi tentang persampahan sebelum lanjut pada peningkatan kualitas sarana persampahan yang dilengkapi dengan komponen smart seperti sensor, GPS, dan lain-lain.
\end{abstract}

Kata kunci: Motivasi, Pemanfaatan Internet, Internet of Things (IoT), Pengelolaan Sampah, SEM (Structural Equation Modeling), Kecamatan Banyumanik

\begin{abstract}
Motivation in the internet usage of waste management is one of the driving factors for realizing Smart Waste Management (SWM). The motivation is intended to be able to change people's behavior in waste management from collect-transport-dump paradigm to reduction and treatment at the generation that can be done through technology assistance in its management system known as the Internet of Things (IoT). The city of Semarang was chosen as one of the cities incorporated in the Movement Towards 100 Smart Cities at the Smart City Summit 2017. However, there is none of internet usage as a tool to reduce waste problems whose success is determined by the community. Banyumanik Subdistrict is the highest number of active waste banks in Semarang. Nevertheless, based on the latest Semarang City Waste Management Masterplan data in 2013, the level of waste services in the Banyumanik District is still 27\%, which is in the 10th position out of 16 Districts in Semarang city. This is not comparable with the waste generation that reaches $365.88 \mathrm{~m}^{3} /$ day and makes Banyumanik District the fourth largest contributor to waste generation in Semarang city. This research collected data from 200 respondents who had been served garbage facilities and had used the internet in Banyumanik District using a 1-7 Likert scale. Using Structural Equation Modeling (SEM), this study examines the factors that influence people's motivation in using the internet for waste management. Based on the sociodemographic, economic and solid waste systems in Banyumanik Subdistrict, the researchers found that knowledge of the internet and recycling factors were the most important factors that influenced people's motivation with a correlation coefficient of 1.02. Another influential factor is the condition of the waste facility itself with a correlation coefficient of 0.74. Thus, this study recommends that the government to promote IoT for waste management such as the existence of educational applications about solid waste before continuing on improving the quality of waste facilities equipped with smart components such as sensors, GPS, and others.
\end{abstract}

Keywords: Motivation, Use of the Internet, Internet of Things (IoT) Waste Management, SEM (Structural Equation Modeling), Banyumanik Subdistrict.

Citation: Vionna., Maryono, M. (2019). Motivasi Masyarakat dalam Pemanfaatan Internet untuk Pengelolaan Sampah. Jurnal Ilmu Lingkungan, 17(2), 291-303, doi:10.14710/jil.17.2.291-303 


\section{Pendahuluan}

Pemanfaatan internet dalam pengelolaan sampah menjadi salah satu strategi dalam perwujudan smart city (Kusuma, 2018). Pemanfaatan internet tidak lagi sebatas untuk berkomunikasi, akan tetapi dapat digunakan untuk menghubungkan suatu barang melalui sensor sehingga menciptakan sistem otomatis yang disebut Internet of Things (IoT) (Bello \& Zeadally, 2017). Dewangan (2018) menyatakan bahwa adopsi IoT merupakan pendekatan yang efektif untuk layanan publik seperti pengelolaan sampah. Kim, Ramos, \& Mohammed (2017) membuktikan melalui risetnya pengelolaan sampah yang menanamkan teknologi IoT akan menghasilkan pengurangan biaya dalam jangka panjang. Hal ini sesuai dengan tujuan SWM yaitu untuk mencapai pengelolaan sampah yang efektif dan terpadu serta mengurangi dampak negatifnya terhadap lingkungan melalui adopsi inovasi teknologi.

Di sisi lain, keberhasilan pemanfaatan internet dalam pengelolaan sampah sangat dipengaruhi memengaruhi oleh keterlibatan dan kesadaran masyarakat. Berdasarkan Theory Planned Behavior (TPB) penentu terpenting perilaku seseorang adalah intensi melalui pemahaman pengaruh-pengaruh motivasional terhadap perilaku tersebut (Ajzen, 1991). Masyarakat memiliki motivasi yang mengarahkan perilaku termasuk untuk melakukan pemanfaatan internet untuk pengelolaan sampah.

Berdasarkan tujuan dari SWM, Kota Semarang yang tergabung dalam Gerakan Menuju 100 Smart city pada Smart City Summit tahun 2017 dalam pengelolaan sampahnya belum dapat dikatakan efektif. Masterplan Persampahan Kota Semarang tahun 2013, tingkat pelayanan persampahan di Kecamatan Banyumanik masih 27\% yaitu berada di posisi ke-10 dari 16 Kecamatan di Kota Semarang. Hal tersebut tidak sebanding dengan timbulan sampah yang mencapai 365,88 m3/hari dan menjadikan Kecamatan Banyumanik penyumbang timbulan sampah terbanyak ke empat se-Kota Semarang. Dinas Lingkungan Hidup (DLH) Kota Semarang tahun 2017 mencatat Kecamatan Banyumanik memiliki jumlah bank sampah aktif terbanyak di Kota Semarang yaitu sebanyak 7 bank sampah yang berpotensi mengurangi 10-20\% volume sampah.

Kondisi tersebut mengindikasikan bahwa peningkatan produksi sampah belum diiringi dengan peningkatan pelayanan dan adanya motivasi masyarakat untuk ikut dalam pengelolaan sampah. Penelitian sebelumnya Rahman (2013), prinsipprinsip umum dalam pengelolaan sampah dapat mencerminkan perilaku masyarakat dalam mengelola sampah. Peneliti lainnya Sukerti (2017) menjadikan ketersediaan layanan persampahan merupakan faktor eksternal yang paling memengaruhi perilaku masyarakat. Pernyataan ini di dukung juga oleh Barr et al. (2001) yang menyatakan bahwa jangkauan layanan sarana persampahan juga memengaruhi perubahan perilaku masyarakat. Dari penelitian tersebut, diketahui kondisi sarana persampahan memengaruhi perilaku. Namun, belum diteliti apa yang dapat memengaruhi motivasi masyarakat untuk melakukan pengelolaan sampah dengan memanfaatkan internet sehingga memunculkan suatu perilaku.

Diatur Pemerintah melalui Undang-Undang Nomor 18 Tahun 2008 tentang Pengelolaan Sampah serta Peraturan Pemerintah Nomor 81 Tahun 2012 tentang Pengelolaan Sampah Rumah Tangga, menyatakan bahwa dibutuhkan perubahan paradigma mendasar pengelolaan sampah dari kumpul-angkut-buang menjadi pengelolaan yang berfokus pada pengurangan dan penanganan sampah. Namun, kendala dalam penerapan prinsip tersebut adalah rendahnya kesadaran masyarakat terhadap nilai dari sampah. Maka dibutuhkan perubahan persepsi masyarakat karena berdampak pada perilaku masyarakat dalam mengelola sampah (Darmawan, 2014). Lebih lanjut, Sidik (2007) menyebutkan perubahan pengetahuan dan sikap masyarakat merupakan awal dari perubahan perilaku. Peneliti sebelumnya Barr et al., (2001) menekankan bahwa sikap seseorang yang melihat adanya nilai lingkungan dipengaruhi oleh pengetahuan individu tersebut. Penelitian lainnya, Vicente \& Reis (2008) melalui temuannya bahwa rumah tangga yang menerima pengetahuan berupa informasi melalui media lebih berpartisipasi dalam daur ulang dibandingkan yang tidak mendapatkan informasi. Maka dari itu, penelitian ini mengidentifikasi apakah pengetahuan juga dapat memengaruhi motivasi masyarakat dalam pemanfaatan internet untuk pengelolaan sampah.

Taylor \& Todd (1995) menjelaskan tiga komponen pendukung yang paling memengaruhi perilaku masyarakat untuk melakukan pengelolaan sampah. Adanya kompatibilitas yaitu tingkat inovasi sesuai dengan potensi adopsi dinilai dari gaya hidup dan pengalaman. Saat ini, DLH Kota Semarang telah merencanakan adanya aplikasi kelola sampah dan pembangunan satu bank sampah tiap kelurahan yang terintegrasi sistem daring. Namun, sebelum menerapkan inovasi tersebut terlebih dahulu perlu ditinjau adaptasi teknologi dan gaya hidup masyarakat dapat memengaruhi motivasi mereka dalam pemanfaatan internet dalam pengelolaan sampah.

Berdaskarkan penelitian sebelumnya yang terbatas pada peninjauan faktor-faktor yang memengaruhi perilaku, pada penelitian ini akan melihat lebih rinci. Penelitian ini mengidentifikasi apa saja faktor-faktor memengaruhi motivasi masyarakat dalam pemanfaatan internet untuk pengelolaan sampah di Kecamatan Banyumanik. Hasilnya, dapat menjadi rekomendasi bagi pemerintah Kota Semarang untuk mendukung perwujudan smart city dalam bidang persampahan. 


\section{Metodologi}

\subsection{Teknik Sampling}

Penelitian ini termasuk pada penelitian kausal (causal research) dengan metode kuantitatif deskriptif survei. Metode ini bertujuan untuk menjelaskan dan meringkas berbagai kondisi, situasi atau variabel yang muncul dalam masyarakat sebagai objek penelitian kemudian menggambarkan tentang variabel agar memenuhi untuk analisis data (Bungin, 2004). Metode ini digunakan untuk mendapatkan data tentang keyakinan, pendapat, karakteristik, perilaku, hubungan variabel dan untuk menguji beberapa hipotesis dari sampel dalam suatu populasi (Sugiyono, 2013).

Tabel 1. Proporsi Sebaran Sampel

\begin{tabular}{lrrr}
\hline \multicolumn{1}{c}{ Kelurahan } & Jumlah KK & Proporsi & Jumlah Sampel \\
\hline Pudak Payung & 6070 & $16 \%$ & 32 \\
Gedawang & 2472 & $7 \%$ & 13 \\
Jabungan & 1083 & $3 \%$ & 6 \\
Padangsari & 3265 & $9 \%$ & 17 \\
Banyumanik & 2883 & $8 \%$ & 15 \\
Srondol Wetan & 5587 & $15 \%$ & 30 \\
Pedalangan & 2960 & $8 \%$ & 16 \\
Sumurboto & 2673 & $7 \%$ & 14 \\
Srondol Kulon & 4618 & $12 \%$ & 25 \\
Tinjomoyo & 2871 & $8 \%$ & 15 \\
Ngesrep & 3138 & $8 \%$ & 17 \\
\multicolumn{1}{c}{ Total } & 37.620 & $100 \%$ & 200 \\
\hline
\end{tabular}

Berdasarkan metode tersebut, teknik pengambilan sampel yang digunakan adalah nonprobability dengan metode purposive sampling dan menggunakan tingkat kesalahan yang ditoleransi sebesar 10\%. Besarnya ukuran sampel disesuaikan dengan model analisis yaitu SEM sehingga digunakan model estimasi Maximum Likelihood Estimation (MLE) yang membutuhkan 100-200 sampel (Ghozali, 2008). Partisipan dalam penelitian ini adalah 200 orang masyarakat yang sudah terlayani sistem persampahan dan sudah menggunakan internet di Kecamatan Banyumanik. Proporsi sampel tiap kelurahan berdasarkan proporsi jumlah KK seperti pada Tabel 1.

\subsection{Variabel Penelitian}

Pemilihan variabel dilakukan dengan mengidentifikasi teori-teori dari penelitian terdahulu yang dilakukan terkait dengan perilaku masyarakat dalam pengelolaan sampah dan pemanfaatan internet. Hubungan kausalitas antar variabel dibangun oleh landasan teori yang mendukungnya. Pada dasarnya, perilaku seseorang sangat dipengaruhi oleh intensi yang didorong dari pengaruh-pengaruh motivasional terhadap perilaku tersebut. Motivasi adalah dorongan mental yang menggerakan dan mengarahkan perilaku manusia atas dasar kebutuhan (Basrowi, 2014). Perilaku ditentukan oleh persepsi dan kepribadian yang dilatarbelakangi oleh pengalaman. Penelitian ini menggunakan TPB sebagai teori dasar perilaku dikemukakan oleh Ajzen (1991). Terdapat tiga komponen utama dalam TPB yaitu attitude, subjective norm, Perceived Behavior Control (PBC). Norma subjektif yang tinggi akan berdampak kepada tingginya motivasi. PBC akan memperkuat motivasi pada kondisi individu mempunyai informasi dan meningkatkan kemampuan (self efficacy) (Ramdhani, 2011).

Tabel 2. Komponen TPB dalam Penelitian terkait Sistem Persampahan Pada Penelitian Sebelumnya

\begin{tabular}{|c|c|c|c|c|}
\hline \multicolumn{2}{|r|}{ Attitude } & Subjective Norm & Perceived Behavior Control & \multirow{2}{*}{$\begin{array}{c}\text { Sumber literatur } \\
\text { Barr, Gilg, \& Ford (2001) }\end{array}$} \\
\hline$\bullet$ & $\begin{array}{l}\text { Persepsi terhadap } \\
\text { sampah dan daur } \\
\text { ulang }\end{array}$ & Tekanan sosial & $\begin{array}{ll}\text { - } & \text { Akses atau jangkauan layanan } \\
& \text { terhadap sarana persampahan } \\
\text { - } & \text { Self efficacy } \\
\text { - } & \text { Pengalaman daur ulang } \\
\text { - } & \text { Pengetahuan }\end{array}$ & \\
\hline$\bullet$ & $\begin{array}{l}\text { Persepsi terhadap } \\
\text { isu lingkungan, } \\
\text { pelestarian, } \\
\text { konservasi SDA, } \\
\text { hemat biaya }\end{array}$ & 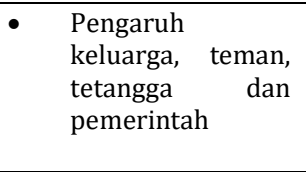 & $\begin{array}{ll}\text { - } & \text { Ketersediaan ruang untuk menyimpan } \\
\text { limbah daur ulang } \\
\text { - } \\
\text { Ketersediaan waktu untuk melakukan } \\
\text { daur ulang } \\
\text { - } \quad \text { Kemudahan akses daur ulang }\end{array}$ & $\begin{array}{l}\text { Davies, Foxall, \& Pallister } \\
\text { (2002) }\end{array}$ \\
\hline & $\begin{array}{l}\text { Manfaat daur ulang } \\
\text { Material dan moral } \\
\text { insentif }\end{array}$ & $\begin{array}{ll}\text { - } & \text { Norma sosial } \\
\text { Dukungan } & \text { dan } \\
\text { kerjasama } & \text { dari } \\
\text { keluarga } & \text { dan } \\
\text { tetangga } & \end{array}$ & 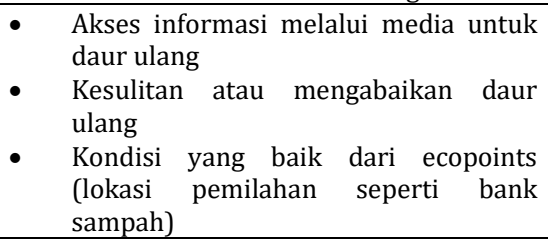 & Vicente \& Reis (2008) \\
\hline & $\begin{array}{l}\text { Persepsi terhadap } \\
\text { isu lingkungan } \\
\text { Manfaat daur ulang }\end{array}$ & $\begin{array}{l}\text { Kepercayaan pada } \\
\text { pengelola sampah }\end{array}$ & \begin{tabular}{ll} 
- & \multicolumn{2}{l}{ Pengalaman daur ulang } \\
- & Kenyamanan akses fasilitas \\
persampahan dan daur ulang \\
- $\begin{array}{l}\text { Pengetahuan tentang pemilahan } \\
\text { sampah }\end{array}$
\end{tabular} & $\begin{array}{l}\text { Vassanadumrongdee } \\
\text { Kittipongvises (2018) }\end{array}$ \\
\hline
\end{tabular}

Lebih lanjut pada model perilaku pengelolaan sampah yang dijabarkan Taylor \& Todd (1995) menjelaskan PCB terdiri dari compatibility, resource facilitating conditions dan self efficacy. Compatibiliy adalah tingkat inovasi sesuai dengan potensi adopsi dinilai dari gaya hidup, pengalaman dan 
pengetahuan. Sedangkan resource facilitating conditions mengacu kepada kemudahan akses terhadap sarana persampahan serta self efficacy adalah kemampuan individu melakukan pengelolaan persampahan.

Berdasarkan uraian beberapa penelitian yang telah dilakukan sebelumnya seperti pada Tabel 2, untuk mengetahui faktor-faktor yang memengaruhi motivasi masyarakat memanfaatkan internet dapat menggunakan dua komponen TPB yaitu norma subjektif dan PBC. Dari identifikasi diatas, peneliti memilih 15 observed variables yang dikelompokkan menjadi 3 variabel laten. Tiga variabel laten tersebut antara lain akses terhadap sarana persampahan, pengetahuan terhadap internet dan daur ulang serta gaya hidup. Pengumpulan data dilakukan dengan instrumen kuisioner yang menggunakan skala pengukuran likert. Skala likert terdiri dari 7 kategori tingkatan jawaban yaitu sangat tidak setuju (1), agak tidak setuju (2), tidak setuju (3), netral (4), agak setuju (5), setuju (6) dan sangat setuju (7). Angka 1 menunjukkan bobot terendah sedangkan angka 7 adalah bobot tertinggi yang diberikan responden terhadap suatu item pernyataan. Indikator-indikator yang digunakan untuk mewakili masing-masing variabel laten dapat dijabarkan seperti pada Tabel 3.

Tabel 3. Variabel Penelitian

\begin{tabular}{|c|c|c|c|}
\hline No. & $\begin{array}{l}\text { Variabel Laten } \\
\text { (Constructs) }\end{array}$ & & Indikator (Observed Variables) \\
\hline \multirow{6}{*}{1} & \multirow{6}{*}{$\begin{array}{l}\text { Kondisi sarana } \\
\text { persampahan } \\
\text { (K) }\end{array}$} & $\mathrm{X} 1$ & $\begin{array}{l}\text { Tidak tersedianya wadah sampah membuat Anda mau memanfaatkan internet untuk pengelolaan } \\
\text { sampah. }\end{array}$ \\
\hline & & $\mathrm{X} 2$ & $\begin{array}{l}\text { Tidak tersedianya sarana (ruang dan alat) untuk pemilahan sampah membuat Anda mau } \\
\text { memanfaatkan internet untuk pengelolaan sampah. }\end{array}$ \\
\hline & & X3 & $\begin{array}{l}\text { Tidak tersedianya sarana pengangkutan sampah skala lingkungan (gerobak atau motor) membuat } \\
\text { Anda mau memanfaatkan internet untuk pengelolaan sampah. }\end{array}$ \\
\hline & & $\mathrm{X} 4$ & $\begin{array}{l}\text { Tidak tersedianya sarana daur ulang (TPST/Bank Sampah) di sekitar lingkungan rumah membuat } \\
\text { Anda mau memanfaatkan internet untuk pengelolaan sampah. }\end{array}$ \\
\hline & & X5 & $\begin{array}{l}\text { Frekuensi pengangkutan sampah yang jarang membuat Anda mau memanfaatkan internet untuk } \\
\text { pengelolaan sampah. }\end{array}$ \\
\hline & & X6 & $\begin{array}{l}\text { Jauhnya lokasi sarana daur ulang (TPST/Bank Sampah) membuat Anda mau memanfaatkan internet } \\
\text { untuk pengelolaan sampah. }\end{array}$ \\
\hline \multirow{5}{*}{2} & \multirow{5}{*}{$\begin{array}{l}\text { Pengetahuan internet } \\
\text { dan daur ulang } \\
\text { (T) }\end{array}$} & $\mathrm{X} 7$ & $\begin{array}{l}\text { Sulitnya mendapatkan informasi melalui media cetak mendorong Anda menggunakan internet untuk } \\
\text { pengelolaan sampah. }\end{array}$ \\
\hline & & $\mathrm{X} 8$ & $\begin{array}{l}\text { Anda mau memanfaatkan internet untuk pengelolaan sampah karena tidak tahu cara melakukan } \\
\text { daur ulang secara mandiri. }\end{array}$ \\
\hline & & X9 & $\begin{array}{l}\text { Anda mau memanfaatkan internet untuk pengelolaan sampah karena ketidaktahuan kebijakan atau } \\
\text { aturan dari pemerintah untuk mengelola sampah rumah tangga. }\end{array}$ \\
\hline & & $\mathrm{X} 10$ & $\begin{array}{l}\text { Tidak mengerti cara pemilahan jenis sampah membuat Anda mau memanfaatkan internet untuk } \\
\text { pengelolaan sampah. }\end{array}$ \\
\hline & & $\mathrm{X} 11$ & $\begin{array}{l}\text { Memanfaatkan internet untuk pengelolaan sampah membuat Anda merasa mendapatkan manfaat } \\
\text { (nilai ekonomi dan lingkungan) yang lebih. }\end{array}$ \\
\hline \multirow{4}{*}{3} & \multirow{4}{*}{$\begin{array}{l}\text { Gaya hidup } \\
\text { (G) }\end{array}$} & $\mathrm{X} 12$ & $\begin{array}{l}\text { Anda mau memanfaatkan internet untuk pengelolaan sampah jika bangunan tempat tinggal Anda } \\
\text { sudah permanen (dari segi konstruksi). }\end{array}$ \\
\hline & & $\mathrm{X} 13$ & $\begin{array}{l}\text { Semakin banyak anggota keluarga membuat Anda merasa lebih mudah mengelola sampah } \\
\text { menggunakan internet (daring). }\end{array}$ \\
\hline & & $\mathrm{X} 14$ & $\begin{array}{l}\text { Sudah memiliki smartphone dan koneksi internet mempermudah Anda memanfaatkan internet } \\
\text { untuk pengelolaan sampah. }\end{array}$ \\
\hline & & $\mathrm{X} 15$ & $\begin{array}{l}\text { Anda mau memanfaatkan internet untuk pengelolaan sampah karena belum pernah melakukan daur } \\
\text { ulang. }\end{array}$ \\
\hline
\end{tabular}

\subsection{Metode Analisis}

Metode analisis yang digunakan pada penelitian ini terdiri atas analisis statistik deskriptif dan analisis statistik inferensial non-parametris. Analisis statistik deskriptif digunakan untuk menggambarkan data yang telah terkumpul dengan tujuan membuat kesimpulan atau generalisasi seperti karakteristik responden, karakteristik pengelolaan sampah eksisting serta analisis variabel perilaku. Sedangkan analisis statistik inferensial yang digunakan dalam penelitian ini lebih lanjut merupakan statistik non parametris untuk menguji hipotesa melalui uji signifikansi untuk generalisasi sampel terhadap populasi menggunakan Structural Equation Modeling (SEM). Analisis SEM dilakukan menggunakan software LISREL untuk memunculkan hubungan antar variabel secara kompleks dan melihat hubungan antar jalur (construct). Secara garis besar, terdapat 4 tahapan dalam analisis SEM, yaitu: a. Spesifikasi, penggambaran sifat dan jumlah parameter model yang telah dikembangkan berdasarkan teori kausalitas menggunakan LISREL dan SIMPLIS seperti pada Gambar 1. Berdasarkan Gambar 1 simbol matematis memiliki makna sebagai berikut:

$\gamma$ : hubungan variabel eksogen dan variabel endogen

$\lambda$ : hubungan variabel laten dan variabel observed

$\delta \quad$ : kesalahan pengukuran pada $\mathrm{X}$

$\mathcal{E}$ : kesalahan pengukuran pada $\mathrm{Y}$

Akses ( $(1 /$ ksi 1) : variabel eksogen

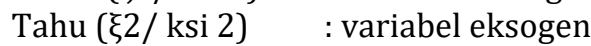

Gaya ( $3 / \mathrm{ksi} 3)$ : variabel eksogen

Perilaku ( $\eta /$ eta) : variabel endogen

$\mathrm{X}$ dan Y :variabel observed (variabel teramati), $\mathrm{X}$ berkaitan dengan variabel eksogen, $Y$ berkaitan dengan variabel endogen. 
b. Identifikasi, menemukan model dengan nilai degree of freedom $>0$, bernilai positif atau overidentified. c. Estimasi, berhubungan dengan heywood cases atau negative error variance, sebagai pertimbangan pengeliminasian pada variabel

d. Uji Kecocokan, pengujian model dengan data sesuai tabel goodness of fit (GOF)

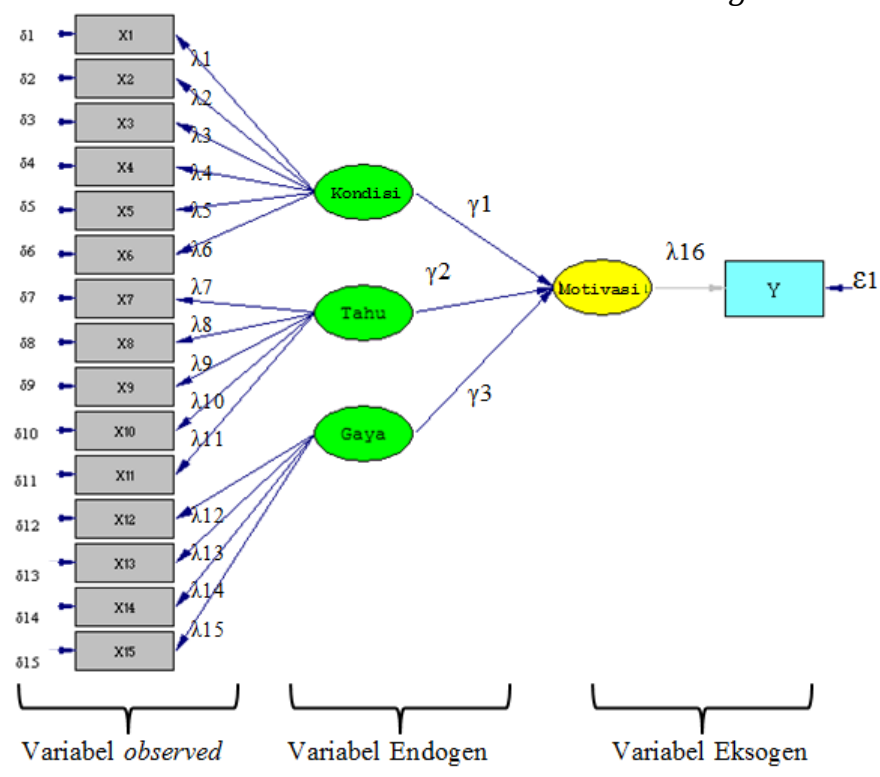

Gambar 1 Model SEM dari Motivasi Masyarakat dalam Pemanfaatan Internet untuk Pengelolaan Sampah Dengan Bentuk path diagram dan Simbol Matematis

\section{Hasil dan Pembahasan}

\subsection{Karakteristik Responden}

Karakteristik responden ditinjau berdasarkan komponen dalam TPB yaitu faktor latar belakang. Identifikasi karakteristik responden terdiri dari aspek sosio demografis dan ekonomi. Karakteristik sosio demografis terdiri atas usia, jumlah anggota keluarga dan tingkat pendidikan. Sedangkan karakteristik ekonomi terdiri dari jenis pekerjaan, jumlah pendapatan dan tipe hunian. Berdasarkan hasil survei, dapat diketahui karakteristik responden sebagai berikut:

a. Responden berusia produktif 25-64 tahun dengan proporsi terbanyak adalah rentang usia 45-54 tahun sebesar 36\%.

b. Jumlah anggota keluarga responden sebesar $50 \%$ terdiri dari 4 orang.

c. Tingkat pendidikan responden $47 \%$ adalah lulusan D3/S1/S2 serta tidak terdapat responden yang tidak bersekolah.

d. Jenis pekerjaan responden sebesar $46 \%$ adalah ibu rumah tangga, diikuti $23 \%$ adalah PNS/TNI/POLRI.

e. Rentang jumlah pendapatan responden berkisar dari $\leq$ Rp700.000 - $\geq$ Rp3.500.000, dominan sebesar $81 \%$ responden memiliki pendapatan $\geq$ Rp3.500.000.

\subsection{Karakteristik Pengelolaan Sampah Eksisting}

Berdasarkan data DLH dan BPS Kota Semarang tahun 2016, produksi sampah harian yang ditimbulkan mencapai total $564,28 \mathrm{~m}^{3}$ yakni meningkat 1,66\% dari tahun 2014. Berdasarkan data DLH dan BPS Kota Semarang tahun 2016, produksi sampah harian yang ditimbulkan mencapai total 564,28 m3 yakni meningkat 1,66\% dari tahun 2014. Hasil survei menunjukkan karakteristik pengelolaan sampah oleh masyarakat di Kecamatan Banyumanik sebagai berikut:

\section{a. Pemilahan}

Dari 200 responden hanya 56 orang yang telah melakukan pemilahan sampah. Sebesar $80 \%$ diantaranya berasal dari responden Kelurahan Gedawang. Hal ini dipengaruhi oleh ketersediaan bank sampah yang ada di masing-masing kelurahan. Berdasarkan karakteristik tersebut, belum sesuai dengan kewajiban masyarakat yang seharusnya melakukan pemilahan sampah sejak dari sumbernya.

\section{b. Pewadahan}

Penyediaan wadah sebesar 98\% disediakan oleh individu dengan $40 \%$ diantaranya melakukan koordinasi penyediaan wadah dengan RT dan RW setempat. Kemudian 2\% lainnya yaitu di Kelurahan Tinjomoyo mendapatkan bantuan wadah sampah dari program KotaKu Dinas Pekerjaan Umum Kota Semarang. Setiap kelurahan dominasi mencapai 58\% hanya memiliki satu wadah. Hal ini belum sesuai dengan kewajiban masyarakat dalam pengelolaan sampah, yaitu seharusnya setiap masyarakat memiliki wadah terpilah antara sampah organik dan non-organik. Ditinjau dari bentuk dan bahan wadah, $74 \%$ responden memiliki wadah berbentuk tong yang berbahan plastik. Sedangkan volume wadah rata-rata adalah 10-40 liter yang sudah sesuai dengan rata-rata volume timbulan sampah serta jadwal pengangkutan sampah yang ada. Sebagian 
besar karakteristik pewadahan responden sudah sesuai dengan SNI 3242-2008 dan SNI 19-2454-2002 yang menjadi acuan dalam pengelolaan sampah rumah tangga.

\section{c. Pengumpulan}

Sistem pengumpulan sampah permukiman di Kecamatan Banyumanik memiliki pola individual tidak langsung. Berdasarkan data dari Masterplan Persampahan Kota Semarang, terdapat 28 TPS yang tersebar di 10 kelurahan Kecamatan Banyumanik. Kelurahan Jabungan merupakan satu-satunya yang tidak memiliki TPS. Hal ini dikarenakan akses yang sulit menuju wilayah Kelurahan Jabungan sehingga tidak dilakukan pengangkutan sampah untuk dibuang ke TPA. Dengan demikian, hak masyarakat unutk pengumpulan sampah khususnya di Kelurahan Jabungan belum terpenuhi.

\section{d. Pengangkutan}

Frekuensi pengangkutan sampah tiap kelurahan sangat bervariasi, hal ini disebabkan oleh $78 \%$ responden menjawab petugas pengangkut sampah berasal dari masyarakat RT/RW terdekat yang kemudian berkoordinasi dengan pihak kelurahan. Sehingga rata-rata frekuensi pengangkutan adalah 12 hari sekali, kecuali Kelurahan Jabungan yang seluruh respondennya dilayani pengangkutan sampah >3hari sekali. Banyaknya masyarakat yang masih tidak ikut pengangkutan disebabkan memiliki lahan luas dan memilih untuk membakar sampah juga menjadi faktor frekuensi pengangkutan sampah yang jarang di Kelurahan Jabungan,

Karakteristik sarana pengangkutan sampah di dominasi sebesar 53\% dari total responden diangkut menggunakan Tossa (motor bak). Namun pada kelurahan Sumurboto di dominasi oleh sarana pengangkutan gerobak, hal ini disebabkan karena lebih banyak akses jalan cenderung sempit dibanding kelurahan lainnya. Responden yang memilih sarana pengangkutan lainnya sebesar 4\% adalah menggunakan sarana truk sampah dari Pemkot Semarang atau sepeda motor tanpa bak seperti di Kelurahan Tinjomoyo (jalan gombel lama).

\section{e. Pengolahan dan daur ulang}

Kecamatan Banyumanik memiliki Bank Sampah Sektoral (BSS) yang memiliki anggota 19 bank sampah dan 5 TPST/TPS 3R dari 8 kelurahan kecuali Kelurahan Srondol Wetan, Sumurboto dan Jabungan. Namun demikian, sebesar $61 \%$ responden belum terlayani dengan ketersediaan bank sampah. Hal ini diperkirakan dipengaruhi oleh jarak terhadap bank sampah yang mempengaruhi minat masyarakat untuk bergabung dalam bank sampah. Responden memiliki jarak yang beragam dengan bank sampah.

Responden yang memiliki jarak <100 meter dengan bank sampah memiliki sistem bank sampah skala dawis atau beberapa rumah yang dilakukan setiap minggu, sistem ini dilakukan oleh 36\% responden. Kemudian untuk jarak 200-500 meter sistem bank sampah yang dilakukan oleh skala RT dilakukan oleh 44\% responden. Sedangkan 20\% responden lainnya memiliki jarak 600-900 hingga $>1 \mathrm{~km}$ dilakukan oleh responden yang mengumpulkan sampah hanya sekali sebulan skala RW atau kelurahan. Namun, responden yang sudah bergabung dengan bank sampah $80 \%$ diantaranya belum merasakan manfaat dari bank sampah. Hal tersebut disebabkan karena sistem bank sampah rata-rata baru intensif dalam 3 bulan sebelum waktu survei yaitu Juli - September 2018.

Pengolahan sampah lainnya seperti kompos hanya dilakukan $8 \%$ dari total responden. Responden mengaku belum paham membuat kompos, kemudian diikuti dengan tidak adanya ruang untuk membuat kompos serta tidak membutuhkan kompos.

\subsection{Karakteristik Pemanfaatan Internet dalam Pengelolaan Sampah}

Pemanfaatan internet dominan dilakukan untuk komunikasi menggunakan aplikasi Whatsapp. Pada umumnya, aplikasi ini digunakan untuk melakukan koordinasi dari bank sampah tingkat RW, sektoral hingga kota. Secara keseluruhan, hanya Bank Sampah Gedawang Asri telah memanfaatkan internet lebih jauh untuk kegiatan promosi melalui media sosial hingga adanya website. Berikut pada Tabel 3. dapat diketahui pemanfaatan internet dalam pengelolaan sampah yang dilakukan masing-masing kelurahan.

Tabel 3. Pemanfaatan internet per kelurahan

\begin{tabular}{|c|c|c|c|}
\hline No. & Kelurahan & $\begin{array}{c}\text { Jenis Pemanfaatan } \\
\text { Internet }\end{array}$ & Fungsi \\
\hline 1 & Pudakpayung & Chatting & $\begin{array}{ll}\text { Koordinasi } & \text { bank } \\
\text { sampah } & \text { Kota } \\
\text { Semarang } & \end{array}$ \\
\hline \multirow[t]{3}{*}{2} & Gedawang & Chating & $\begin{array}{l}\text { Koordinasi } \\
\text { sampah } \\
\text { Semarang }\end{array}$ \\
\hline & & Media Sosial & $\begin{array}{l}\text { Promosi hasil } \\
\text { kerajinan dan } \\
\text { laporan kegiatan }\end{array}$ \\
\hline & & Halaman website & $\begin{array}{lr}\text { Informasi } & \text { lengkap } \\
\text { kegiatan } & \text { dan } \\
\text { kontak } & \end{array}$ \\
\hline 3 & Jabungan & Belum ada & - \\
\hline 4 & Padangsari & Chatting & $\begin{array}{lr}\text { Koordinasi } & \text { bank } \\
\text { sampah } & \text { Kota } \\
\text { Semarang } & \\
\text { Penyebaran } & \\
\text { informasi } & \text { kepada } \\
\text { nasabah } & \text { melalui } \\
\text { grup whatsapp PKK }\end{array}$ \\
\hline 5 & Banyumanik & Chatting & $\begin{array}{ll}\text { Koordinasi } & \text { bank } \\
\text { sampah } & \text { Kota } \\
\text { Semarang } & \end{array}$ \\
\hline 6 & $\begin{array}{l}\text { Srondol } \\
\text { Wetan }\end{array}$ & Chatting & $\begin{array}{l}\text { Menghubungi } \\
\text { pengepul untuk } \\
\text { mengangkut dan } \\
\text { menjual sampah }\end{array}$ \\
\hline 7 & Pedalangan & Chatting & $\begin{array}{lr}\text { Koordinasi } & \text { bank } \\
\text { sampah Kota } & \\
\text { Semarang } & \\
\text { Menghubungi } & \\
\text { pengepul untuk } \\
\text { mengangkut dan } \\
\text { menjual sampah }\end{array}$ \\
\hline 8 & Sumurboto & Belum ada & - \\
\hline 9 & $\begin{array}{c}\text { Srondol } \\
\text { Kulon }\end{array}$ & Chatting & $\begin{array}{l}\text { Koordinasi } \\
\text { sampah }\end{array}$ \\
\hline
\end{tabular}




\begin{tabular}{|c|c|c|c|}
\hline No. & Kelurahan & $\begin{array}{c}\text { Jenis Pemanfaatan } \\
\text { Internet }\end{array}$ & Fungsi \\
\hline 10 & Tinjomoyo & Chatting & 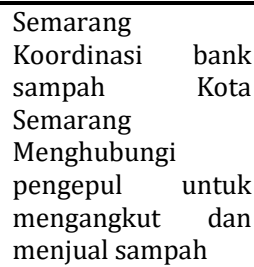 \\
\hline 11 & Ngesrep & Chatting & $\begin{array}{ll}\text { Koordinasi } & \text { bank } \\
\text { sampah } & \text { Kota } \\
\text { Semarang } & \end{array}$ \\
\hline
\end{tabular}

\subsection{Analisis Variabel}

Analisis statistik deskriptif dari 15 variabel observed dilakukan untuk melihat hubungan antara faktor latar belakang dengan jawaban yang dipilih responden pada kuisioner perilaku.

\section{Ketersediaan wadah sampah}

Responden sebesar $47 \%$ tidak melihat korelasi antara tersedianya wadah sampah dengan meningkatnya kemauan dalam pemanfaatan internet untuk pengelolaan sampah. Responden berpendapat bahwa kepemilikan wadah merupakan kewajiban masyarakat untuk menjaga kebersihan lingkungan, sehingga tidak memengaruhi responden dalam pemanfaatan internet untuk pengelolaan sampah. Ditinjau dari karakteristik pewadahan, seluruh responden sudah memiliki wadah sampah. Berdasarkan teori TPB, pilihan jawaban berkemungkinan didasarkan pada normative beliefs atau norma sosial yaitu kewajiban masyarakat dalam pengelolaan sampah adalah memiliki wadah sampah.

Di sisi lain, responden Kelurahan Pudak Payung, Pedalangan, Sumurboto, Srondol Kulon dan Tinjomoyo dominan memilih opsi agak setuju hingga sangat setuju lebih banyak dibandingkan opsi lainnya. Terbatas 2 TPS yang melayani kelurahankelurahan tersebut sehingga responden melihat adanya korelasi antara ketersediaan wadah sampah dengan pemanfaatan internet untuk pengelolaan sampah. Responden berpendapat jika tidak ada wadah sampah maka masyarakat akan rutin melakukan penjemputan sampah dengan memanfaatkan internet karena dapat menentukan waktu pengangkutan sampah.

\section{Ketersediaan sarana pemilahan sampah}

Sebesar 65\% dari total responden memilih jawaban agak setuju hingga sangat setuju. Diketahui pada karakteristik pemilahan bahwa selain Kelurahan Gedawang, lebih dari 50\% responden tiap kelurahan belum melakukan pemilahan sampah. Lebih lanjut, pilihan tersebut didukung dengan alasan bahwa untuk melakukan pemilahan sampah dibutuhkan membutuhkan minimal dua wadah. Selain belum terlayani sarana pengolahan sampah dan daur ulang, faktor sarana ruang dan alat seperti wadah terpisah, ruang untuk meletakkan wadah, ruang untuk mengolah sampah organik, dan lain-lain dianggap sulit untuk dipenuhi. Jika sampah yang sudah dipilah akan disetor ke bank sampah maka harus ditumpuk terlebih dahulu hingga tanggal pengumpulan.

Kelurahan Banyumanik dan Gedawang dengan persentase berturut-turut $40 \%$ dan 38\%. Responden menyatakan bahwa kegiatan pemilahan tidak menyulitkan. Hal ini tentu juga dipengaruhi faktor adanya keaktifan komunitas bank sampah. Kedua kelurahan tersebut merupakan dua tertinggi untuk kelurahan dengan responden terbanyak sudah melakukan pemilahan. Selain itu, diketahui bahwa Kelurahan Gedawang sudah memiliki bank sampah setiap RW sehingga pemilahan sampah agar dapat di proses di bank sampah meskipun tidak memiliki ruang dan alat untuk melakukan pemilahan.

\section{Ketersediaan sarana pengangkutan sampah}

Responden melihat adanya korelasi antara tidak tersedianya sarana pengangkutan sampah akan meningkatkan pemanfaatan internet untuk pengelolaan sampah mencapai $85 \%$. Hal tersebut dilatarbelakangi oleh jumlah TPS yang sedikit bahkan tidak tersedia, tidak terjadwalnya pengangkutan sampah serta sarana daur ulang yang tidak cukup melayani seluruh masyarakat. Dengan demikian, adanya pemanfaatan internet dengan permintaan penjemputan via daring diharapkan akan memudahkan pengelolaan sampah, karena dapat melakukan penjemputan sampah sesuai kebutuhan dan dapat meningkatkan pelayanan pengangkutan sampah ke wilayah yang belum terlayani

Sementara itu, responden yang berpendapat tidak setuju dari Kelurahan Pudak Payung, Srondol Kulon dan Srondol Wetan menganggap sarana pengangkutan tidak berkorelasi dengan pemanfaatan internet. Pilihan tersebut dipengaruhi ketersediaan jumlah TPS yang lebih banyak dibanding delapan kelurahan lainnya, sehingga TPS lebih mudah dijangkau jika harus melakukan pengumpulan sampah secara individual mandiri.

\section{Ketersediaan sarana daur ulang}

Pilihan dengan persentase terbanyak sebesar $38 \%$ responden adalah setuju bahwa tidak tersedianya sarana daur ulang akan meningkatkan kemauan memanfaatkan internet untuk pengelolaan sampah. Berdasarkan karakteristik persampahan, masyarakat belum merasakan manfaat daur ulang serta terbatasnya sarana tersebut. Internet untuk daur ulang yang sudah banyak dilakukan dan menghadirkan keuntungan secara pribadi dianggap menggiurkan bagi masyarakat.

Berbeda dengan Kelurahan Gedawang, responden dominan menjawab tidak setuju sebesar 46\%. Di Kelurahan Gedawang kegiatan bank sampah sudah dilakukan sejak tahun 2015, ketua bank sampah mengaku sangat sulit untuk mendapatkan perhatian masyarakat agar mau bergabung dengan bank sampah. Ketersediaan bank sampah di setiap RW menjadikan rutinitas daur ulang tidak hanya mendatangan manfaat ekonomi namun juga sosial, sehingga masyarakat sudah terbiasa dengan sistem bank sampah terjadwal. 


\section{Frekuensi pengangkutan sampah}

Sebesar $70 \%$ responden setuju bahwa ada korelasi antara frekuensi pengangkutan sampah dengan pemanfaatan internet. Ditinjau berdasarkan frekuensi pengangkutan sampah, kondisi pengangkutan sampah eksisting ternyata berpengaruh terhadap pilihan jawaban responden. Kelurahan dengan frekuensi penjemputan yang dominan dua hingga lebih dari tiga hari sekali cenderung setuju dengan pernyataan indikator ini. Kondisi tersebut terjadi pada Kelurahan Jabungan dengan frekuensi pengangkutan lebih dari tiga hari sekali, sedangkan Kelurahan Sumurboto terdapat responden dengan jadwal pengangkutan sampah yang tidak menentu. Selain itu, Kelurahan Tinjomoyo yang terlayani dengan frekuensi pengangkutan sampah satu hingga tiga hari setuju dengan korelasi karena kondisi topografi yang cukup curam pada beberapa RW dan akses jalan yang cukup sempit sehingga sarana pengangkut yang bisa digunakan terbatas. Kondisi tersebut menyebabkan beberapa kali sampah tidak diangkut lebih dari jadwal yang sudah ditentukan. Lebih lanjut, responden berpendapat bahwa sampah tidak baik untuk didiamkan terlalu lama karena dapat menimbulkan bau serta dapat berpengaruh pada kesehatan.

Di sisi lain, responden di Kelurahan Gedawang memiliki kegiatan daur ulang untuk mengurangi tumpukan sampah. Sedangkan Kelurahan Banyumanik dan Srondol Wetan memiliki anggota keluarga rata-rata dua orang terbanyak sehingga timbulan yang dihasilkan lebih sedikit.

\section{Jarak lokasi sarana daur ulang (Bank sampah)}

Seluruh responden kecuali dari Kelurahan Gedawang dominan setuju adanya korelasi antara jarak lokasi sarana daur ulang terhadap pemanfaatan internet untuk pengelolaan sampah. Pilihan responden tersebut tentu dipengaruhi oleh ketersediaan sarana daur ulang dan jarak lokasi menuju sarana daur ulang tersebut. Ketersediaan sarana daur ulang di Kecamatan Banyumanik berjumlah 19 yang tersebar hanya di 8 dari 11 kelurahan yang ada sehingga sebesar $61 \%$ belum terlayani dengan bank sampah. Responden Kelurahan Jabungan paling dominan setuju karena tidak terdapat sarana daur ulang.

Kelurahan Gedawang memiliki responden terbanyak yang menyatakan tidak ada korelasi antara jarak lokasi sarana daur ulang dengan pemanfaatan internet. Karakteristik jarak lokasi bank sampah responden di Kelurahan Gedawang berkisar antara 100 dan 200-500 meter dari hunian. Lebih lanjut responden Kelurahan Banyumanik, Srondol Wetan dan Padangsari dipengaruhi oleh jenis pekerjaan responden dominan adalah PNS dan karyawan swasta yang sudah melakukan kegiatan daur ulang di tempat bekerja. Selain itu usia responden yang rata-rata diatas 54 tahun juga dapat mempengaruhi minat responden dalam memanfaatkan internet.

\section{Mendapatkan informasi melalui media (internet)}

Dominan responden merasakan adanya korelasi antara akses informasi melalui internet terhadap pemanfaatan internet untuk pengelolaan sampah. Austin et. Al (1993) dalam Vicente \& Reis (2008) menyatakan bahwa masyarakat dengan pengetahuan yang baik terhadap daur ulang lebih ingin berpartisipasi dalam kegiatan daur ulang dibanding yang kurang pengetahuannya. Lebih lanjut cara paling efektif untuk menyebarkan informasi selain melalui direct media seperti papan iklan dan informasi resmi dari pemerintah adalah menggunakan direct mailings atau pesan yang ditujukan personal. Responden belum sampai kepada tahapan itu, akan tetapi populernya aplikasi whatsapp yang dapat menyebarkan informasi secara langsung ke personal meningkatkan intensitas responden untuk melakukan akses internet

Akan tetapi, berbeda dengan Kelurahan Gedawang, Banyumanik, Sumurboto dan Srondol Wetan masih terdapat responden yang memilih opsi sangat tidak setuju, tidak setuju dan agak tidak setuju. Ditinjau dari karakteristik sosio-demografis, empat kelurahan tersebut memiliki karakteristik usia dan tingkat pendidikan yang sama. Jumlah responden berusia diatas 54 tahun lebih banyak dibanding delapan kelurahan lainnya. Selain itu, responden dari empat kelurahan tersebut masih terdapat yang berpendidikan rendah yaitu lulusan SD dan SMP.

\section{Cara melakukan daur ulang}

Responden dominan setuju bahwa tidak tahu cara melakukan daur ulang akan meningkatkan pemanfataan internet untuk pengelolaan sampah mencapai $84 \%$. Ditinjau dari karakteristik sistem persampahan, kegiatan pemilahan ternyata berpengaruh terhadap pilihan jawaban responden. Hal ini dibuktikan bahwa Kelurahan Gedawang, Padangsari, Banyumanik dan Pedalangan secara berurutan memiliki tingkat tertinggi responden yang telah melakukan pemilahan sampah. Lebih lanjut, ketersediaan sarana daur ulang terdekat seharusnya mampu menjadi wadah bagi masyarakat agar lebih berkompetensi untuk melakukan daur ulang dan meyakinkan masyarakat bahwa mereka melakukan hal yang tepat (Vicente \& Reis, 2008). Seiring dengan tidak adanya sarana daur ulang yang tersedia, sehingga masyarakat sangat minim informasi yang biasanya didapatkan dari sosialisasi tentang daur ulang.

\section{Kebijakan untuk melakukan daur ulang}

Pada Kelurahan Pudak Payung, Sumurboto, Srondol Kulon dan Tinjomoyo responden dominan setuju bahwa ada korelasi antara kebijakan dan daur ulang. Ditinjau dari karakteristik sosio-demografis seperti tingkat pendidikan dan jenis pekerjaan 
ternyata tidak berpengaruh terhadap pilihan jawaban responden. Jika dibandingkan dengan karakteristik sistem persampahan aspek teknis juga tidak memengaruhi pilihan jawaban responden. Kebijakan lebih berhubungan dengan program sosialisasi yang dilaksanakan oleh Pemerintah Kota Semarang yaitu tergolong kepada aspek non teknis. Hal ini dibuktikan dengan Kelurahan Pedalangan, Gedawang, Padangsari dan Banyumanik yang memiliki KSM cenderung tidak setuju karena tentu akan lebih sering melakukan sosialisasi dari tingkat RW hingga RT terkait kebijakan untuk melakukan daur ulang

\section{Pemilahan jenis sampah}

Responden di Kecamatan Banyumanik yang merasakan korelasi dan tidak merasakan korelasi dari pengetahuan pemilahan jenis sampah dengan pemanfaatan internet memiliki perbedaan persentase yang tidak signifikan. Kelurahan Gedawang, Padangsari dan Banyumanik memiliki responden dominan tidak setuju. Hal ini ternyata masih dipengaruhi oleh tingkat responden yang sudah melakukan pemilahan. Namun, responden dari delapan kelurahan lainnya dominan memilih opsi setuju. Melalui internet responden dapat mengetahui bahwa jenis sampah tidak hanya organik dan anorganik serta plastik terdiri dari berbagai jenis yang membutuhkan cara daur ulang yang berbeda. Hal ini masih dipengaruhi dengan terbatasnya iklan dan sosialisasi yang dilakukan pihak-pihak terkait dalam memberikan informasi dasar seperti pemilahan sampah.

\section{Manfaat daur ulang}

Kelurahan Gedawang, Padangasari dan Banyumanik memiliki responden yang konsisten dengan pernyataan sebelumnya yaitu dominan memilih opsi tidak setuju. Responden tidak melihat adanya korelasi antara manfaat daur ulang dengan pemanfaatan internet. Lebih lanjut, responden berpendapat bahwa tanpa adanya internet kegiatan daur ulang yang sudah ada cukup mendatangkan manfaat dari segi ekonomi maupun lingkungan. Namun, berbeda dengan delapan kelurahan lainnya yang juga termasuk dari $80 \%$ masyarakat belum merasakan manfaat dari bank sampah. Menggunakan internet akan memungkinkan sampah yang di daur ulang memiliki nilai ekonomi lebih tinggi seperti dengan promosi daring, melakukan pencatatan tabungan bank sampah secara daring sehingga dapat mengurangi biaya kertas untuk buku tabungan dan lain-lain.

\section{Tipe tempat tinggal}

Sebesar 51\% dari total responden cenderung tidak melihat adanya korelasi antara jenis hunian dengan pemanfaatan internet. Ditinjau dari karakteristik jenis hunian, sosio-demografi dan ekonomi ternyata tidak mempengaruhi jawaban responden. Hal ini menunjukkan bahwa penggunaan internet saat ini bukan lagi dipengaruhi oleh karakteristik tersebut karena biaya penggunaan internet yang semakin murah maka memungkinkan siapa saja menggunakan internet. Di sisi lain, Kelurahan Pudak Payung, Sumurboto dan Tinjomoyo memiliki dominan responden memilih opsi agak setuju hingga sangat setuju. Anggapan bahwa Kecamatan Banyumanik yang terdiri dari banyak komplek perumahan baik skala kecil hingga besar, pada umumnya rumah yang sudah permanen menunjukkan ekonomi yang menengah ke atas sehingga penggunaan internet pasti lebih mungkin dilakukan.

\section{Ukuran rumah tangga}

Total responden yang melihat adanya korelasi antara ukuran rumah tangga dengan pemanfaatan internet mencapai 68\%. Responden berpendapat besarnya ukuran rumah tangga tentu berpengaruh dengan meningkatnya jumlah timbulan sampah, namun tidak terbukti jika ditinjau dari karakteristik jumlah anggota keluarga. Di sisi lain, Kelurahan Gedawang dan Srondol Wetan memiliki pertimbangan bahwa ukuran rumah tangga tidak selalu mencerminkan kemauan dalam pemanfaatan internet. Jika satu rumah tangga terdiri dari dua orang yang sudah berusia lanjut, maka akan lebih cenderung memilih mengelola sampah sendiri dibandingkan menggunakan internet. Sementara itu, jika ukuran rumah tangga dua orang usia produktif dan memiliki kesibukan, maka tentu bisa jadi akan memanfaatkan internet dalam pengelolaan sampahnya. Ditelaah lebih lanjut, banyaknya proporsi responden berusia diatas 54 tahun memungkinkan memengaruhi pilihan jawaban sangat tidak setuju hingga agak tidak setuju oleh responden pada variabel ini.

\section{Kepemilihan smartphone}

Sebesar $87 \%$ responden di Kecamatan Banyumanik melihat adanya korelasi antara kepemilikan smartphone dengan pemanfaatan internet untuk pengelolaan sampah. Hal ini tentu merupakan implikasi dari kriteria responden yang dipilih dalam penelitian ini adalah masyarakat yang sudah menggunakan internet. Lebih lanjut, responden berpendapat bahwa menggunakan smartphone lebih mudah untuk dipelajari penggunaannya, dibanding menggunakan internet dari komputer atau gadget lainnya. Disisi lain, masih terdapat pilihan yang tergolong pada non-korelasi dengan memilih tidak setuju dan agak tidak setuju seperti di Kelurahan Pudak Payung, Banyumanik dan Srondol Kulon. Responden dengan pilihan tersebut menyatakan bahwa penggunaan internet hanya sebatas chatting melalui whatsapp, sehingga jika digunakan untuk pengelolaan sampah akan sulit dilakukan. Jumlah responden rentang usia yang lebih dari 55 tahun ternyata melatarbelakangi pilihan responden tersebut. 


\section{Pengalaman daur ulang}

Responden yang melihat adanya korelasi antara pengalaman daur ulang terhadap pemanfaatan internet untuk pengelolaan sampah lebih banyak dibandingkan yang tidak, yaitu sebesar $68 \%$. Dibuktikan melalui kuesioner, sebesar 88\% responden belum melakukan daur ulang yang dapat diperkirakan melatarbelakangi pilihan jawaban responden untuk variabel ini. Lebih lanjut, karakteristik pengelolaan sampah responden di Kecamatan Banyumanik sudah ada sejak tahun 2016, namun kegiatan baru aktif pada pertengahan tahun 2018. Salah satu bukti terdapat pada buku tabungan bank sampah, sehingga jika baru dilakukan selama dua bulan dapat dikatakan pengalaman daur ulang responden masih minim.

Di sisi lain, responden dari Kelurahan Gedawang, Banyumanik dan beberapa responden yang memilih opsi tidak setuju hingga agak tidak setuju dari kelurahan lainnya dipengaruhi oleh jumlah responden yang telah merasakan manfaat dari bank sampah dan yang telah melakukan komposting.

Hasil dari perhitungan persentase pilihan jawaban responden yang merasakan adanya korelasi antara variabel-variabel terhadap pemanfaatan internet, dapat diketahui peringkat kelurahan yang memiliki ketertarikan untuk memanfaatkan internet. Pada Gambar $\mathbf{2}$ ditunjukkan bahwa peringkat tersebut tidak dipengaruhi lokasi secara spasial. Kelurahan dengan peringkat pertama dapat menjadi yang paling tertarik dan membutuhkan penerapan internet untuk persampahan dalam hal ini yaitu Kelurahan Tinjomoyo. Di sisi lain, Kelurahan Gedawang berada pada peringkat terakhir. Hal ini berarti bahwa kondisi pengelolaan sampah Kelurahan Gedawang saat ini sudah memadai dan telah terdapat beberapa pemanfaatan internet dalam pengelolaan sampahnya.

\subsection{Analisis SEM}

Tahapan analisis terdiri dari screening data menggunakan SPSS untuk uji validitas, reliabilitas dan normalitas. Jika data sudah lolos dari ketiga uji SPSS, selanjutnya dilakukan screening menggunakan LISREL untuk membuktikan normalitas data. Data yang sudah normal kemudian akan dilakukan estimasi analisis SEM.

\subsubsection{Screening SPSS}

a. Reliabilitas, uji ini dilakukan dengan cara membandingkan nilai Cronbach's Alpha dengan R tabel. Hasil menunjukkan nilai Cronbach's Alpha sebesar 0,893 yang kemudian akan dibandingkan dengan nilai $r$ hitung untuk data 200 responden. Perhitungan untuk R tabel (N-2) memiliki nilai 0,1166. Berdasarkan perbandingan tersebut dapat diketahui bahwa nilai Cronbach's Alpha lebih besar dari pada R Tabel sehingga data diakui reliabel dan dapat dipercaya.

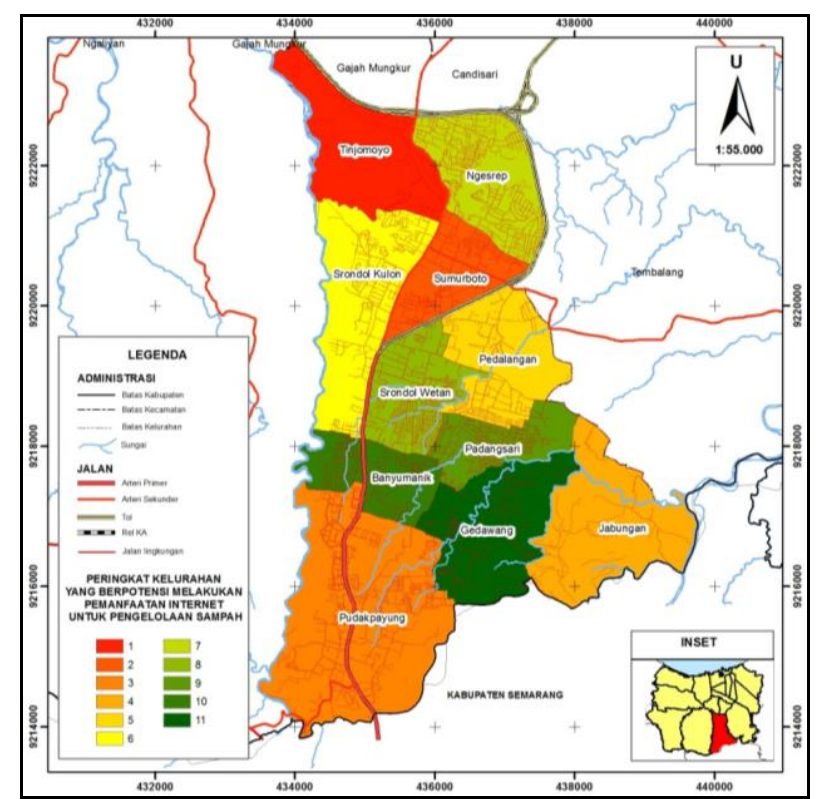

Gambar 2. Peta Peringkat Kelurahan Berpotensi Melakukan Pemanfaatan Internet untuk Pengelolaan Sampah

b. Validitas, uji ini menggunakan korelasi Bivariate Pearson yang kemudian dibandingkan dengan nilai $\mathrm{R}$ tabel untuk setiap variabel. Dari tabel Correlations, diketahui bahwa setiap variabel memiliki nilai Pearson Correlation diatas R tabel yaitu 0,1166. Dengan demikian dapat disimpulkan bahwa pernyataan yang digunakan adalah valid untuk mengukur variabel yang digunakan.

c. Normalitas, Uji normalitas dilakukan dengan metode standar Kolmogorov Smirnov, apabila nilai Asymp Sig. lebih besar dari 0,05 maka data berdistribusi normal. Hasil uji menunjukkan nilai lebih besar dari signifikasi 0,05 yaitu Asymp. Sig sebesar 0,2. Dengan demikian dapat diketahui bahwa data terdistribusi normal.

\subsubsection{Screening LISREL}

Uji normalitas yang dilakukan dengan LISREL memiliki ketelitian lebih tinggi dibandingkan dengan SPSS. Hal yang perlu diperhatikan adalah kolom Skewness and Kurtosis, suatu data dapat dikatakan normal apabila p-value pada kolom tersebut lebih besar dari signifikasi yaitu 0,05 . Hasil menunjukkan bahwa data belum memenuhi asumsi kedua tes normalitas. Dengan demikian, solusi yang dilakukan adalah menerapkan normal score dari data mentah. Hasil uji normalitas yang dilakukan dengan menggunakan data yang sudah dinormalkan menujukkan hasil yang lebih baik. Dapat dilihat pvalue pada kolom Skewness and Kurtosis memiliki nilai diatas 0,05 namun masih terdapat beberapa variabel yang bernilai dibawah 0,05 .

Ghozali (2008) menjelaskan bahwa dalam beberapa penelitian dengan data continous asumsi normalitas tidak dapat dipenuhi dan diatasi dengan beberapa opsi yaitu: 
a. Mengasumsikan bahwa data yang tidak normal akan dijalankan berdasarkan pada keadaan normal seperti biasa, dalam kata lain mengestimasikan model yang salah karena data tidak normal;

b. Mengestimasikan model dengan menggunakan metode ML (Maximum Likelihood) dengan menggunakan Asymptotic Covariance Matrix yang akan mengoreksi biasnya chi-square dan standar error.

\subsubsection{Interpretasi Hasil SEM}

a. Path Model

Pada path diagram terdapat nilai loading factor yang menunjukkan tingkat hubungan antar masingmasing variabel. Berdasarkan analisis yang telah dilakukan melalui dua asumsi, tidak terdapat perubahan yang signifikan terhadap nilai antar variabel yang ditunjukkan pada diagram. Penambahan asymptotic covariance matrix pada analisis hanya memperbaiki nilai chi-square. Perubahan tersebut menurunkan nilai chi-square dari 577,05 menjadi 478,06. Hal ini sesuai yang diharapkan karena dengan kecilnya nilai chi-square, maka dianggap model akan semakin akurat. Namun sebelum melakukan uji kecocokan model menggunakan GOFI, nilai loading factor variabel yang ditampilkan pada path diagram memiliki nilai yang harus dipenuhi. Idealnya nilai loading factor berkisar diantara 0,5 - 0,8 dan tidak melebihi satu, perbaikan nilai dapat dilakukan dengan mengatur error variance/covariance (Wijanto, 2008). Nilai loading factor juga digunakan untuk mengukur tingkat valid sebuah indikator. Ghozali (2008) menjelaskan bahwa loading factor $>0,5$ mengindikasikan bahwa indikator valid digunakan dalam sebuah model. Kemudian untuk reliabilitas variabel laten dapat diukur menggunakan perbandingan nilai $\mathrm{CR} \geq 0,7$ dan VE $\geq 0,4$. Sedangkan reliabilitas variabel observed dilihat dari nilai R2, dimana semakin besar nilai R2 menunjukkan semakin reliabel suatu indikator tersebut.

Pada Gambar 3, dapat diketahui bahwa loading factor untuk observed variable memiliki nilai rentang 0,43 - 0,72. Maka variabel X14 tidak dilakukan analisis validitas serta reliabilitas karena loading factor tidak mencukupi batas diterima. Hal ini dapat disebabkan karena variasi data pada jawaban kuisioner. Apabila variasi data rendah, sulit dijadikan alat ukur karena nilai hampir sama. Kemudian loading factor dari variabel laten lebih bervariasi. Akses Sarana Persampahan (A) diukur melalui 6 variabel observed dan seluruh variabel berkorelasi positif terhadap perilaku dengan nilai 0,74 maka loading factor masih diterima. Kemudian Pengetahuan tentang Internet dan Daur Ulang (T) yang terdiri dari 5 variabel observed juga seluruhnya berkorelasi positif terhadap perilaku namun memiliki nilai 1,02. Sedangkan variabel Gaya Hidup (G) terbukti tidak berkorelasi karena memiliki nilai negatif sebesar 0,66. Pada loading factor variabel laten ditemukan kasus offending estimates (nilai hasil estimasi melebihi batas yang diterima) yaitu nilai yang bernilai negatif (heywood cases) serta nilai yang mendekati atau melebihi 1 . Hair et al, 1998 dalam Wijanto (2008) menyatakan bahwa kasus offending estimates disebabkan oleh model yang dibentuk membutuhkan lebih banyak justifikasi teori.

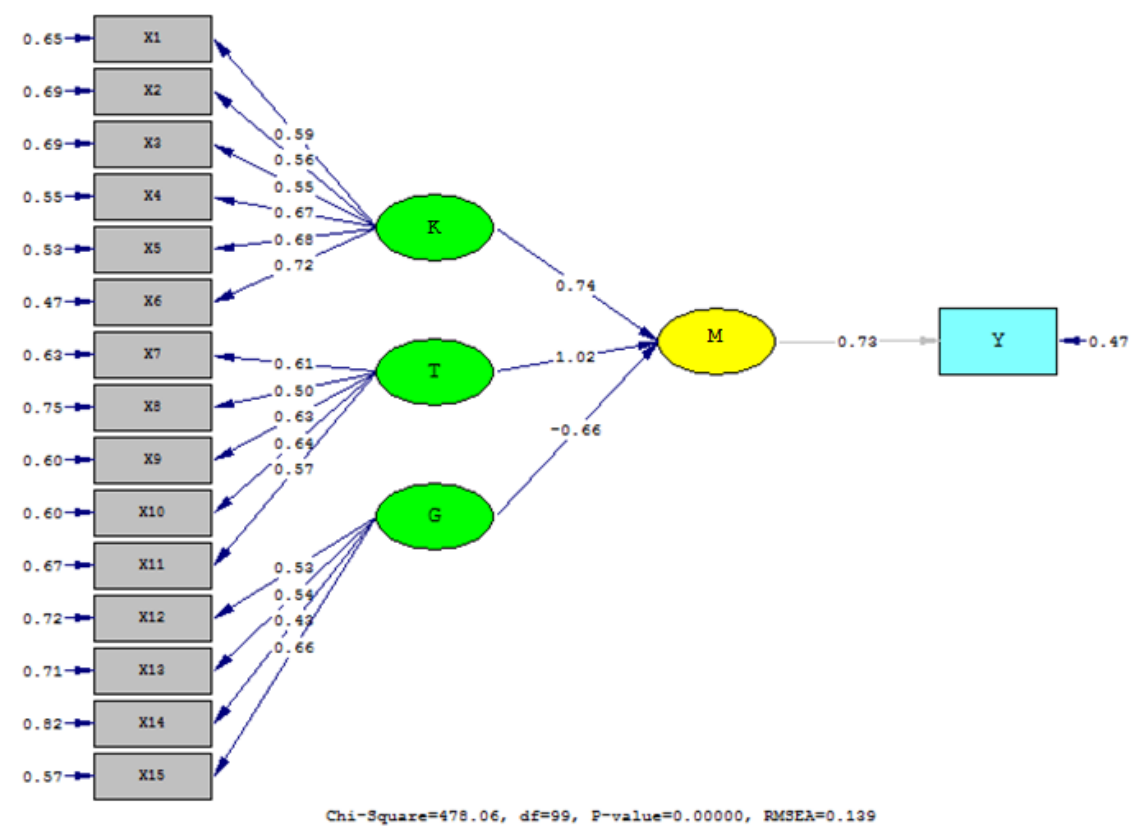

Gambar 3. Hasil SEM Motivasi Masyarakat dalam Pemanfaatan Internet untuk Pengelolaan Sampah di Kecamatan Banyumanik

Berdasarkan nilai loading factor tersebut, dapat diketahui seluruh variabel observed kecuali X14 adalah valid. Demikian pula dengan variabel laten $\mathrm{K}$ dan $\mathrm{T}$ adalah valid, namun variabel $\mathrm{G}$ tidak valid. Uji reliabilitas dilakukan dengan melihat nilai CR dan VE serta nilai $\mathrm{R}^{2}$. Dari perhitungan, diketahui bahwa hanya variabel laten $\mathrm{K}$ yang reliabel, sedangkan variabel $\mathrm{T}$ kurang reliabel dan variabel $\mathrm{G}$ tidak 
reliabel. Sedangkan untuk variabel observed X6 adalah indikator paling reliabel yang memiliki nilai 0,52 .

b. Model Fit

SEM tidak memiliki satu uji statistik terbaik untuk menjelaskan kekuatan prediksi model yang dilakukan, sehingga peneliti mengembangkan beberapa indikator ukuran Goodness Of Fit (GOF). Tidak satupun komponen dari GOF dapat digunakan secara eksklusif untuk dasar evaluasi kecocokan model (Wijanto, 2008). Interpretasi GOF Indices terbagi atas tiga indices type (kelompok) yaitu absolute fit measures, incremental fit measures dan parsimonius fit measures.

Tabel 3. Perbandingan Hasil GOFI

\begin{tabular}{|c|c|c|c|c|c|c|}
\hline \multirow{2}{*}{ Indices type } & \multirow{2}{*}{ Goodness of fit Index } & \multirow{2}{*}{ Cut-off Value } & \multicolumn{2}{|c|}{ Asumsi 1 (tanpa ACM) } & \multicolumn{2}{|c|}{ Asumsi 2 (dengan ACM) } \\
\hline & & & Hasil & Keterangan & Hasil & Keterangan \\
\hline \multirow{5}{*}{ Absolute Fit } & Chi Square & Diharapkan Kecil & 577,05 & GOF kurang baik & 478,06 & GOF lebih baik \\
\hline & GFI & $>0.90$ & 0,73 & GOF kurang baik & 0,73 & GOF kurang baik \\
\hline & RMSEA & $0.05-0.08$ & 0,16 & GOF kurang baik & 0,14 & GOF kurang baik \\
\hline & P Value for RMSEA & $>0.05$ & 0 & $G O F$ kurang baik & 0 & GOF kurang baik \\
\hline & Degree of freedom & Diharapkan Besar & 99 & GOF baik & 99 & GOF baik \\
\hline \multirow{4}{*}{$\begin{array}{l}\text { Incremen } \\
\text {-tal fit }\end{array}$} & AGFI & $\geq 0.90$ & 0,63 & GOF kurang baik & 0,63 & GOF kurang baik \\
\hline & NFI & $>0.90$ & 0,86 & GOF mendekati baik & 0,85 & GOF mendekati baik \\
\hline & CFI & $>0.90$ & 0,88 & GOF mendekati baik & 0,88 & GOF mendekati baik \\
\hline & IFI & $>0.90$ & 0,88 & GOF mendekati baik & 0,88 & GOF mendekati baik \\
\hline \multirow{5}{*}{$\begin{array}{l}\text { Persimo } \\
\text {-nious fit }\end{array}$} & AIC & $\begin{array}{l}<\text { AIC Saturated dari } \\
\text { independent Model }\end{array}$ & $\begin{array}{c}272,00 \\
<\text { dari } \\
3362,92\end{array}$ & GOF baik & $\begin{array}{c}272,00 \\
<\text { dari } \\
3362,92\end{array}$ & GOF baik \\
\hline & ECVI & $\begin{array}{c}<\text { ECVI Saturated dari } \\
\text { independen Model }\end{array}$ & $\begin{array}{l}1,337 \\
<\text { dari } \\
16,55\end{array}$ & GOF baik & $\begin{array}{l}1,337 \\
<\text { dari } \\
16,55\end{array}$ & GOF baik \\
\hline & PGFI & $>0.60$ & 0,53 & GOF mendekati baik & 0,53 & GOF mendekati baik \\
\hline & PNFI & $0.06-0.09$ & 0,71 & GOF kurang baik & 0,71 & GOF kurang baik \\
\hline & NCP & $\begin{array}{c}\text { < Independence Model } \\
(557,4)\end{array}$ & 478,05 & GOF baik & 478,05 & GOF baik \\
\hline
\end{tabular}

Hasil interpretasi GOFI menunjukkan tidak seluruh indikator termasuk pada kategori baik. Setidaknya dibutuhkan lima nilai fit yang termasuk dalam kategori baik dan mewakili seluruh indices type agar model dapat dianggap fit (Latan, 2012). Namun pada incremental fit belum terdapat nilai GOF yang baik, sehingga pada penelitian berikutnya dibutuhkan modifikasi untuk meningkatkan nilai GOF.

\section{Kesimpulan}

Berdasarkan analisis variabel motivasi masyarakat dalam pemanfaatan internet untuk pengelolaan sampah, diketahui bahwa karakteristik sosio-demografis, ekonomi dan kondisi eksisting pengelolaan sampah mempengaruhi pilihan jawaban responden. Analisis jawaban responden yang dilakukan dengan melihat rinci per kelurahan dapat menunjukkan wilayah yang paling tertarik atau membutuhkan pemanfaatan internet untuk pengelolaan sampah. Penelitian ini melakukan uji terhadap model yang dibangun dari pengumpulan teori terkait motivasi, pemanfaatan internet dan pengelolaan sampah. Hasil analisis SEM menunjukkan bahwa dari tiga variabel laten yang diuji, hanya dua variabel yang terbukti berpengaruh terhadap motivasi masyarakat yaitu kondisi sarana persampahan dan pengetahuan tentang daur ulang serta internet. Problematika jarak yang dapat mengurangi minat masyarakat dalam daur ulang diatasi melalui pemanfaatan internet, sehingga adanya faktor kemudahan dan kenyamanan akan meningkatkan minat daur ulang. Terbukti pada penelitian ini variabel pengetahuan terhadap internet dan daur ulang ternyata berimplikasi pada motivasi masyarakat memanfaatkan internet untuk pengelolaan sampah.

Hasil analisis SEM menunjukkan dua variabel laten yang berpengaruh yaitu akses terhadap sarana persampahan dan pengetahuan terhadap internet dan daur ulang. Jika dikaitkan dengan analisis variabel, hal ini berarti keterbatasan sarana dan minimnya pengetahuan masyarakat terhadap internet dan daur ulang akan meningkatkan pemanfaatan internet untuk pengelolaan sampah. Pada akhirnya dari hasil analisis SEM yang telah dilakukan, penelitian ini membuktikan bahwa komponen dari TPB yaitu PBC yang dimodifikasi dapat digunakan untuk mengetahui faktor-faktor yang memengaruhi motivasi masyarakat dalam pemanfaatan internet untuk pengelolaan sampah di Kecamatan Banyumanik. Hal tersebut dibuktikan dengan dihasilkan dua variabel dengan 11 indikator yang berpengaruh terhadap motivasi masyarakat. 
Jika dikaitkan dengan penerapan smart waste management, faktor-faktor yang memengaruhi motivasi masyarakat ternyata berkaitan dengan tiga komponen IoT yaitu fisik, smart dan konektivitas. Sehingga lebih lanjut variabel yang berpengaruh tersebut dapat meningkatkan tingkat pemanfaatan IoT di Kecamatan Banyumanik.

Rekomendasi yang diberikan dari penelitian ini kepada Pemerintah Kota Semarang melalui DLH dalam pengembangan pengelolaan sampah yang memanfaatkan internet perlu terlebih dahulu melakukan pengumpulan data masyarakat terhadap kondisi sarana persampahan. Hal ini dilakukan karena keterbatasan pelayanan persampahan akan memengaruhi peningkatan pemanfaatan internet di masyrakat. Adanya database yang dapat dipantau secara daring memungkinkan pemerintah untuk melakukan kontrol terhadap pengelolaan sampah. Setelah adanya database, pemerintah kemudian dapat mempertimbangkan terlebih dahulu wilayah yang belum terlayani sarana persampahan secara optimal sebagai sasaran. Lebih lanjut, pemerintah dapat meningkatkan kualitas sarana persampahan dengan menambahkan komponen smart seperti sensor, GPS, dll. Selain itu, kemajuan teknologi dapat dimanfaatkan untuk meningkatkan pengetahuan masyarakat. Menanggapi minimnya pengetahuan terhadap pengelolaan sampah dan daur ulang, maka DLH perlu meluncurkan aplikasi yang bersifat edukatif dan responsif terhadap masalah persampahan.

\section{PERNYATAAN}

Sebagian dari riset ini dibiayai oleh Direktorat Riset dan Pengabdian kepada Masyarakat, Kementerian Riset, Teknologi dan Pendidikan Tinggi, dengan kontrak No.101-147/UN7.P4.3/2018

\section{DAFTAR PUSTAKA}

Ajzen, I. (1991). The Theory of Planned Behavior: Organizational Behavior and Human Decision Processes. Retrieved from https://people.umass.edu/ aizen/index.html
Barr, S., Gilg, A. W., \& Ford, N. J. (2001). A Conceptual Framework for Understanding and Analysing Attitudes Towards Household-Waste Management. Environment and Planning $A$, 33(11), 2025-2048. https://doi.org/10.1068/a33225

Davies, J., Foxall, G. R., \& Pallister, J. (2002). Beyond the Intention-behaviour Mythology: An Integrated Model of Recycling. Marketing Theory, 2(1), 29-113. https://doi.org/10.1177/14705931020020016 45

Ghozali, I. (2008). Structural Equation Modelling Teori, Konsep dan Aplikasi dengan Program LISREL 8.80. Semarang: Badan Penerbit Universitas Diponegoro.

Kusuma, L. T. W. N. (2018, February 13). Membangun E-Waste, Mengelola Sampah Lebih Mudah. Kompas.com. Retrieved from https://nasional.kompas.com/read/2018/02/1 3/05030001/membangun-e-waste-mengelolasampah-lebih-mudah

Ratya, M. P. (2017, May 24). Strategi Wali Kota Semarang Terapkan Smart City. Detiknews.com. Retrieved from https://news.detik.com/berita/d3510613/strategi-wali-kota-semarangterapkan-smart-city

Taylor, S., \& Todd, P. (1995). An Integrated Model of Waste Management Behavior. Enviornment and Behavior, 27, 603-630.

Vassanadumrongdee, S., \& Kittipongvises, S. (2018). Factors influencing source separation intention and willingness to pay for improving waste management in Bangkok, Thailand. Sustainable Environment Research, 28(2), 90-99. https://doi.org/10.1016/j.serj.2017.11.003

Vicente, P., \& Reis, E. (2008). Factors influencing households' participation in recycling. Waste Management and Research, 26(2), 140-146. https://doi.org/10.1177/0734242X07077371

Wijanto, S. H. (2008). Structural Equation Modeling dengan LISREL 8.8 Konsep \& Tutorial (Pertama). Yogyakarta: Graha Ilmu. 